\title{
Ross River virus disease in inland NSW: higher than average notifications in 2007-08
}

\author{
Julie A. Tall ${ }^{\mathrm{A}, \mathrm{C}}$, Anthony M. Brown ${ }^{\mathrm{B}}$, \\ Therese C. Jones ${ }^{\mathrm{A}}$ and Catherine A. McKenna ${ }^{\mathrm{A}}$ \\ ${ }^{\mathrm{A}}$ Population Health Division, Greater Western Area Health Service \\ ${ }^{\mathrm{B}}$ School of Rural Health, The University of Sydney \\ ${ }^{\mathrm{C} C o r r e s p o n d i n g ~ a u t h o r . E m a i l: ~ j u l i e . t a l l @ g w a h s . h e a l t h . n s w . g o v . a u ~}$
}

\begin{abstract}
This study showed that Ross River virus notifications in the Greater Western Area Health Service of NSW were higher in 2007-08 than any other financial year for the 1997-2009 period. The study also examined the epidemiology of those notifications. Notification and population data were retrieved from the NSW Health Notifiable Diseases Database and HOIST Populations Library respectively. Age-standardised notification rates were highest in Bogan, Bourke, Brewarrina, Gilgandra, Narromine, Walgett and Warren. Notifications peaked for the 35-39-year age group and were evenly distributed between the sexes. Notifications peaked in February. Aboriginal status was under-reported.
\end{abstract}

Ross River virus (RRV) is endemic in Australia, ${ }^{1}$ with epidemics occurring more commonly in rural than urban locations. ${ }^{2,3}$ Inland New South Wales (NSW) reports some of the highest notification rates in the state. ${ }^{4}$ In the 12 months from 1 July 2007 to 30 June 2008, the Greater Western Area Health Service (GWAHS) experienced its highest number of RRV notifications for the 12-year period between 1 July 1997 and 30 June 2009. Most notifications were received from north-west and central-west local government areas.

\section{Methods}

Notification data and variables of sex, age, aboriginality and date of disease onset were retrieved from the NSW Health Notifiable Diseases Database (NDD) for the 12 years between 1997 and 2009. Population data were retrieved for the same period. This information was obtained from a population health database held by the NSW Department of Health (Health Outcomes Information and Statistical Toolkit). Notifications were examined for financial years rather than calendar years, since RRV activity peaks during summer months. ${ }^{2}$ Notification and population data were used to calculate age-standardised notification rates (ASNRs).

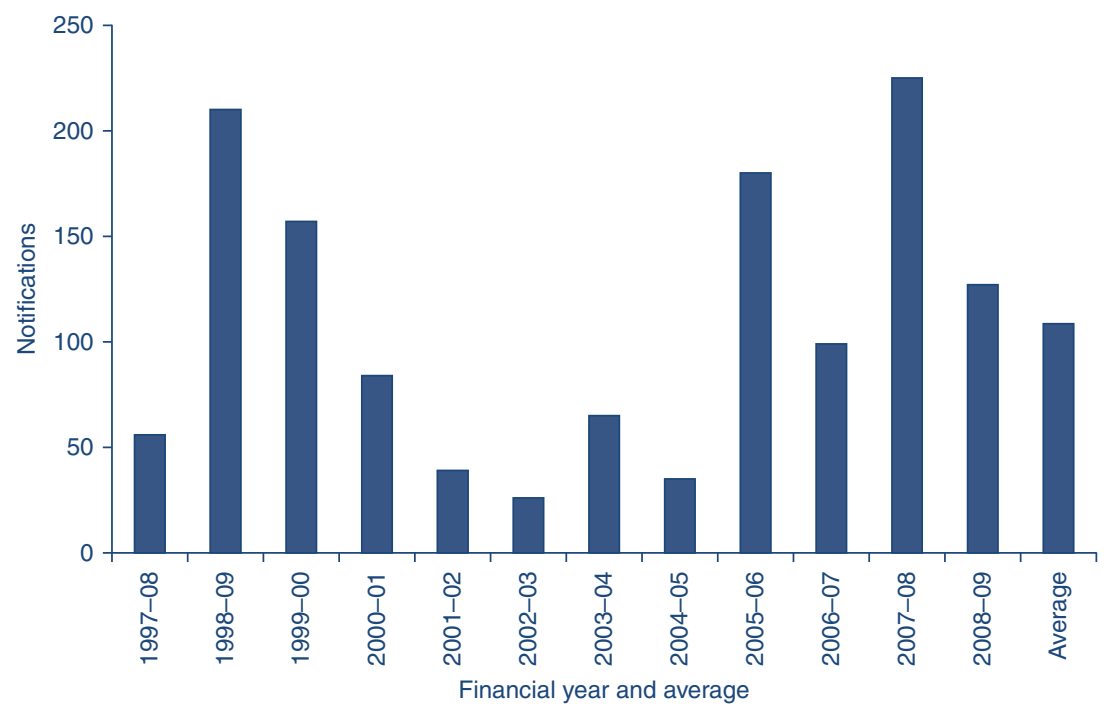

Figure 1. Number of Ross River virus notifications in the Greater Western Area Health Service, 1 July 1997-30 June 2009, and the average number of notifications for this period.

Source: Notifiable Diseases Database accessed through Health Outcomes and Information Statistical Toolkit, NSW Department of Health. 
Table 1. Age-standardised notification rate and number of Ross River virus notifications in all local government areas of the Greater Western Area Health Service, 2007-08

\begin{tabular}{|c|c|c|}
\hline $\begin{array}{l}\text { Local government } \\
\text { area }\end{array}$ & $\begin{array}{l}\text { Age-standardised } \\
\text { notification rate }\end{array}$ & Notifications \\
\hline Balranald & 0.0 & 0 \\
\hline Bathurst Regional & 2.6 & 1 \\
\hline Blayney & 0.0 & 0 \\
\hline Bogan & 410.5 & 12 \\
\hline Bourke & 565.5 & 18 \\
\hline Brewarrina & 201.0 & 4 \\
\hline Broken Hill & 35.6 & 7 \\
\hline Cabonne & 0.0 & 0 \\
\hline Central Darling & 101.7 & 2 \\
\hline Cobar & 98.9 & 5 \\
\hline Coonamble & 46.9 & 2 \\
\hline Cowra & 0.0 & 0 \\
\hline Dubbo & 129.3 & 52 \\
\hline Forbes & 83.1 & 8 \\
\hline Gilgandra & 344.2 & 16 \\
\hline Lachlan & 188.8 & 13 \\
\hline Mid-Western Regional & 31.7 & 7 \\
\hline Narromine & 206.5 & 14 \\
\hline Oberon & 0.0 & 0 \\
\hline Orange & 13.3 & 5 \\
\hline Parkes & 47.1 & 7 \\
\hline $\begin{array}{l}\text { Unincorporated Far } \\
\text { West }\end{array}$ & 0.0 & 0 \\
\hline Walgett & 237.5 & 17 \\
\hline Warren & 215.4 & 6 \\
\hline Warrumbungle Shire & 188.5 & 19 \\
\hline Weddin & 26.7 & 1 \\
\hline Wellington & 11.6 & 1 \\
\hline Wentworth & 42.4 & 3 \\
\hline
\end{tabular}

Source: Notifiable Diseases Database accessed through Health Outcomes and Information Statistical Toolkit, NSW Department of Health.

\section{Results}

The average number of RRV notifications for 1997-2009 was 109 (Figure 1), while in 2007-08, 225 notifications were recorded - more than double the average.

Notifications were not evenly distributed across all local government areas for 2007-08 (Table 1).

Bourke had the highest ASNR followed by Bogan and Gilgandra. Walgett, Warren, Narromine and Brewarrina all had ASNRs over 200. Nearly $40 \%$ of all notifications occurred in these seven local government areas. Lachlan and Warrumbungle Shire each had an ASNR of 188 with 13 and 19 cases respectively. Dubbo had the highest number of notifications (52) but also the largest population, resulting in an ASNR of only the tenth highest.

In 2007-08, the majority of notifications (62\%) occurred in January, February and March (Figure 2). Cases peaked in February 2008 with $26.7 \%$ of the total notifications for the 12 -month period. A second peak occurred from September to November 2007 with 48 cases for this period (21\% of the total for the year). The winter months (June, July and August) had the lowest number, with 15 notifications or $6.8 \%$ of the total.

Most notifications (88\%) were in people aged 15-69 years (Figure 3). More than half (58\%) were aged 30-59 years, with the highest number of cases (26) in the 35-39-year age group. A high number of notifications (15) also fell in the 15-19-year age group. Notifications in young children and teenagers up to 14 years of age and people aged 75 years and over were low - less than $2.5 \%$ for each of the six age groups. Infants and children tend to be asymptomatic and therefore are generally under-diagnosed for RRV infection. ${ }^{2,3,5}$ The elderly, however, may retain immunity from previous infection, and are unlikely to be reinfected. ${ }^{1,5}$

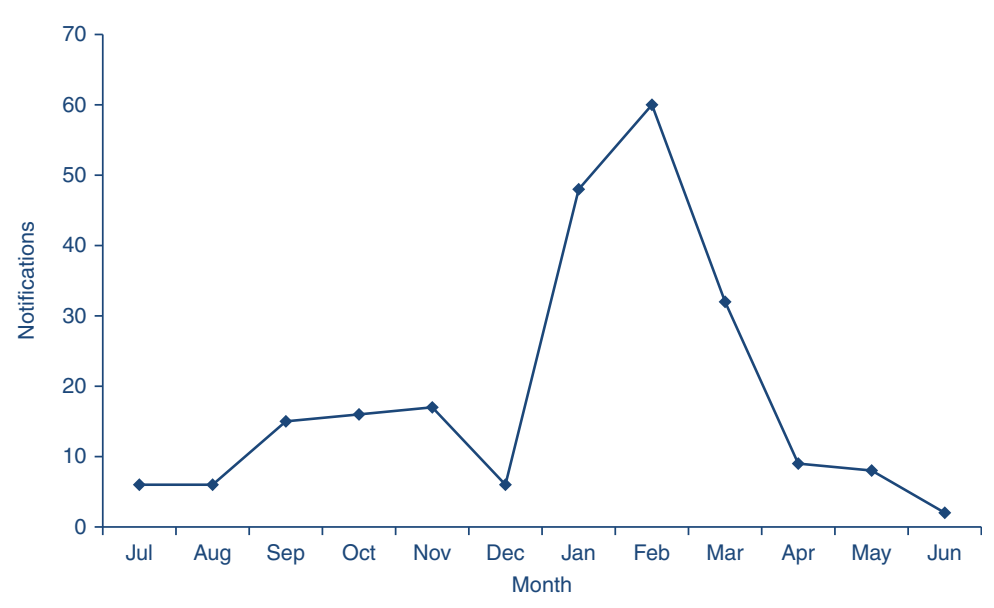

Figure 2. Monthly distribution of Ross River virus notifications in the Greater Western Area Health Service, 1 July 2007-30 June 2008. and Information Statistical Toolkit, NSW Department of Health. 


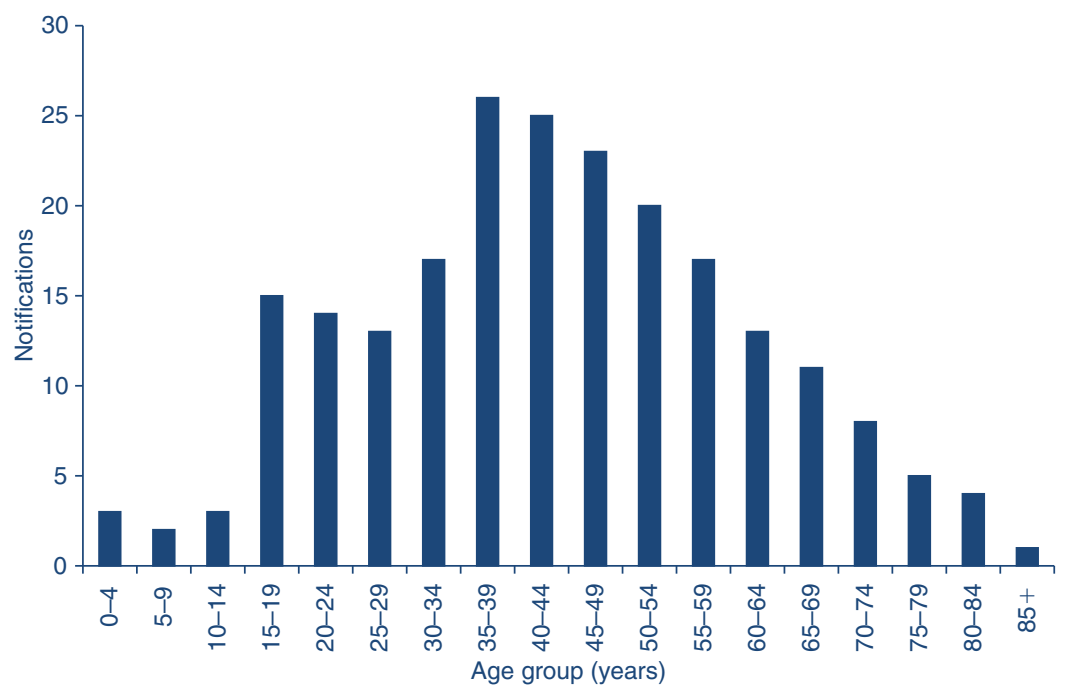

Figure 3. Number of Ross River virus notifications for each age group in the Greater Western Area Health Service, 2007-08.

Source: Notifiable Diseases Database accessed through Health Outcomes and Information Statistical Toolkit, NSW Department of Health.

Male notifications were $51.1 \%$ of the total; males are $50.3 \%$ of the population in GWAHS. This was generally consistent with the sex distribution of cases reported elsewhere. ${ }^{3,5,6}$

Aboriginal status was 'not stated' for more than $65 \%$ of cases, and for the entire area, only two out of 220 cases were reported as being Aboriginal people. In NSW, Aboriginal status is not a required field for laboratory requests, nor is it mandatory to identify Aboriginal status for the NDD (Population Health Unit, GWAHS, pers. comm., 7 September 2009).

\section{Limitations of notification data}

While the detection of Ross River-specific IgM is sufficient for a confirmed case to be recorded on the NDD, the Public Health Laboratory Network regards the detection of Ross River-specific IgM as suggestive evidence only since IgM for the alphaviruses, such as RRV, may persist for months to years. ${ }^{7}$ Furthermore, although the Department of Medical Entomology advises that blood tests be performed at both acute and convalescent phases, ${ }^{2}$ NDD data indicate that many cases are laboratory-tested only once. Thus the detection of single-point Ross River-specific IgM could simply indicate prior infection and therefore not all RRV notifications may have been recent cases of the disease. The high notifications may reflect a true increase in RRV infection or simply an increase in testing. The possible reasons behind the higher than average RRV notifications for GWAHS in 2007-08 are worthy of investigation.

\section{Acknowledgments}

Graeme Robson, Population Health, GWAHS, for his assistance in sourcing NDD data; and the Health Outcomes and Information
Statistical Toolkit, Centre for Epidemiology and Research, NSW Department of Health.

\section{References}

1. Communicable Diseases Network Australia. Department of Health and Ageing. Ross River Virus Infection. Available from: http://www.health.gov.au/internet/main/publishing.nsf/ Content/health-arbovirus-pdf (Cited 2 February 2009.)

2. Department of Medical Entomology, University of Sydney and Westmead Hospital. Ross River and Barmah Forest Virus. Available from: http://medent.usyd.edu.au/fact/ ross\%20river\%20\&\%20barmah\%20forest.htm (Cited 9 October 2008.)

3. Russell RC. Ross River virus: ecology and distribution. Annu Rev Entomol 2002; 47: 1-31. doi:10.1146/annurev.ento.47. 091201.145100

4. Doggett $\mathrm{S}$. Population health aspects of mosquito-borne disease in New South Wales. NS W Public Health Bull 2004; 15(11-12): 193-9. doi:10.1071/NB04042

5. Horwood CM, Bi P. The incidence of Ross River virus disease in South Australia, 1992 to 2003. Commun Dis Intell 2005; 29(3): 291-6.

6. Harley D, Sleigh A, Ritchie S. Ross River virus transmission, infection, and disease: a cross-disciplinary review. Clin Microbiol Rev 2001; 14(4): 909-32. doi:10.1128/CMR.14.4. 909-932.2001

7. Public Health Laboratory Network. 2001. Laboratory case definitions: Alphavirus and flavivirus laboratory case definitions. Department of Health and Ageing, Australian Government. Available from: http://www.health.gov.au/ internet/main/publishing.nsf/Content/cda-phlncd-flavivirus (Cited 8 October 2008.) 